\title{
Evaluation of Immunological Safety of Topiramate, an Anti-epileptic Drug, in a Murine Model
}

\author{
Sang-Bae $\mathrm{HAN}^{1}$, Jee Youn $\mathrm{KIM}^{1}$, Soon Woo KwoN ${ }^{1}$, Jong Soon $\mathrm{KANG}^{3}$, Hwan Mook KIM ${ }^{3}$, \\ Sukgil SoNG ${ }^{1}$, Jin Tae HoNG ${ }^{1}$, Youngsoo $\mathrm{KIm}^{1}$, and Won Seop Kıм ${ }^{2, *}$ \\ ${ }^{1}$ College of Pharmacy and ${ }^{2}$ College of Medicine, Chungbuk National University, Cheongju 361-763, \\ ${ }^{3}$ Korea Research Institute of Bioscience and Biotechnology, Ochang 363-883, Republic of Korea
}

(Received February 9, 2009; Revised March 17, 2009; Accepted March 18, 2009)

\begin{abstract}
Epilepsy is one of the most common neurological disorders, and topiramate (TPM) is one of the most effective drugs that can render patients seizure-free. The focus of the present study was to evaluate the immunological safety of TPM in a mouse model. We examined the in vitro effect of TPM on immune functions of BV2 microglial cells, RAW 264.7 macrophages, B cells, T cells, and dendritic cells. We also examined the in vivo effect of TPM on mouse immune organs, such as lymph node, spleen, and thymus. When cells were directly treated with TPM at concentrations from 1 to $30 \mu \mathrm{g} / \mathrm{ml}$, TPM did not affect nitrite production by BV2 cells and macrophages, proliferation of B cells and T cells, or maturation of dendritic cells. In addition, TPM did not change the weight and cellularity of lymph nodes, spleen, and thymus in vivo at doses from 3 to 100 $\mathrm{mg} / \mathrm{kg}$ injected i.p. into mice once a day for 4 consecutive days. These data showed that TPM, which is widely used as an anti-epileptic drug, is immunologically safe.
\end{abstract}

Keywords: Topiramate, Anti-epileptic drug, Adverse effect, Immune functions

\section{INTRODUCTION}

Topiramate (TPM) is one of the latest anti-epileptic drugs (AEDs) available for treating drug-resistant partial epilepsy in both adults and children (Latini et al., 2008). TPM is a structurally novel broad-spectrum AED with established efficacy as monotherapy or adjunctive therapy in the treatment of adult and pediatric patients with generalized tonic-chronic seizures, partial seizures with or without generalized seizures, and seizures associated with Lennox-Gastaut syndrome (Lyseng-Williamson and Yang, 2007; Lyseng-Williamson and Yang, 2008). The mechanisms underlying TPM anti-epileptic activity are still incompletely understood. Multiple mechanisms of action have been shown in preclinical studies, including sodium and calcium channel blockade, $\gamma$-aminobutyrate potentiation, and glutamate receptor antagonism (White, 1997; White et al., 1997; DeLorenzo et al., 2000; Gibbs et al., 2000). The efficacy of TPM as adjunctive therapy is supported by several clinical trials (Ben-Menachem, 1996;

${ }^{*}$ Corresponding author

Tel: +82-43-269-6044 Fax: +82-43-268-2732

E-mail: wskim@chungbuk.ac.kr
Ben-Menachem et al., 1996; Faught et al., 1996; Privitera et al., 1996; Sharief et al., 1996; Tassinari et al., 1996; Yen et al., 2000). Responder rates were 35 to $48 \%$ with daily doses ranging from 300 to $800 \mathrm{mg}$.

Adverse effects that were seen more commonly for patients taking TPM than placebo in clinical trials included ataxia, decreased concentration, confusion, dizziness, and fatigue (Shorvon, 1996; Rosenfeld, 1997; Rosenfeld et al., 1997; Sachdeo et al., 2002; French et al., 2004a; French et al., 2004b). TPM also decreased serum estradiol levels by $30 \%$ and serum digoxin levels by $12 \%$ (Rosenfeld et al., 1997; Sachdeo et al., 2002). Two adverse events of interest were shown in clinical studies: renal stones and weight loss (Wasserstein and Hedges, 1995; Rosenfeld et al., 1997). TPM was a weak inhibitor of carbonic anhydrase. Although this inhibition was not related to anti-epileptic activity, (Maryanoff et al., 1987), it might be related to renal calculi so that $1.5 \%$ of patients treated with TPM developed renal stones (Wasserstein and Hedges, 1995). Weight loss was also reported in patients during the clinical trials (Rosenfeld et al., 1997). Another side effect was paresthesia, which might also be associated with the inhibition of carbonic anhydrase. Paresthesia appeared to decrease 
with time or with dosage reduction.

Although the safety of TPM has been evaluated in many clinical and preclinical studies, no immunological safety has been reported to date. Here, we examined the effect of TPM on the functions of several immune cells, including microglial cells, macrophages, B cells, T cells, and dendritic cells in a murine model.

\section{MATERIALS AND METHODS}

\section{Nitric oxide production by BV2 microglial cells and RAW 264.7 macrophages}

The immortalized murine BV2 cell line, which exhibits both the phenotypic and the functional properties of reactive microglial cells, was obtained from American Type Culture Collection (Bethesda, MD) (Moon et al., 2005). Cells were cultured in Dulbecco's modified Eagle's medium supplemented with $10 \%$ fetal bovine serum (Invitrogen, Carlsbad, CA), $2 \mathrm{mM}$ L-glutamine, $100 \mathrm{U} / \mathrm{ml}$ penicillin, and $100 \mu \mathrm{g} / \mathrm{ml}$ streptomycin. RAW 264.7 cells (murine macrophage line) were obtained from American Type Culture Collection (Bethesda, MD). Cells were grown in RPMI 1640 supplemented with $10 \%$ fetal bovine serum, $2 \mathrm{mM}$ glutamine, $100 \mathrm{U} / \mathrm{ml}$ penicillin, and $100 \mu \mathrm{g} / \mathrm{ml}$ streptomycin. For the nitrite production assay, $1 \times 10^{5}$ cells were plated on 24-well culture plates (Jeon et al., 2000). $\mathrm{NO}_{2}{ }^{-}$accumulation in the medium was an indicator of $\mathrm{NO}$ production, as previously described. After $24 \mathrm{hr}$, the isolated supernatants were mixed with an equal volume of Griess reagent $(1 \%$ sulfanilamide, $0.1 \%$ naphthylethylenediamine dihydrochloride, and $2 \%$ phosphoric acid) and incubated at room temperature for $10 \mathrm{~min}$. Nitrite production was determined by measuring optical density at $540 \mathrm{~nm}$ using $\mathrm{NaNO}_{2}$ to generate a standard curve.

\section{Proliferation of $B$ and $T$ cells}

Female C57BL/6 mice (6-8 weeks old) were obtained from Korea Research Institute (Chungbuk, Korea). Mice were housed in specific pathogen-free conditions at 21$24^{\circ} \mathrm{C}$ and $40-60 \%$ relative humidity under a $12 \mathrm{~h}$ light/dark cycle. All animals were acclimatized for at least 1 week prior to the experiments. The experimental procedures used in this study were approved by the KRIBB Animal Experimentation Ethics Committee. Spleen cells were freed of red blood cells through lysis buffer treatment (Han et al., 1998). Cells were cultured in RPMI 1640 medium supplemented with $10 \%$ fetal calf serum, $2 \mathrm{mM}$ glutamine and $50 \mu \mathrm{M}$ 2-mercaptoethanol (Sigma, St. Louis, MO). T or B cells were stimulated with $1 \mu \mathrm{g} / \mathrm{ml}$ of Con A or LPS for 72 $\mathrm{hr}$, respectively. Cells were pulsed with $1 \mu \mathrm{Ci} /$ well of $\left[{ }^{3} \mathrm{H}\right]$-thymidine (113 Ci/nmol, NEN, Boston, MA) for the last $18 \mathrm{hr}$ and harvested with an automated cell harvester (Inotech, Dottikon, Switzerland). The amount of [ $\left.{ }^{3} \mathrm{H}\right]$-thymidine incorporated into the cells was measured using a Wallac Microbeta scintillation counter (Wallac, Turku, Finland).

\section{Maturation of dendritic cells}

DCs were generated from bone marrow (BM) cells obtained from 6-7-week-old female mice (Kim et al., 2007). Briefly, BM cells were flushed out of femurs and tibias. After red blood cells were lysed, whole BM cells $\left(2 \times 10^{5}\right.$ cells $/ \mathrm{ml}$ ) were cultured in $100-\mathrm{mm}^{2}$ culture dishes in 10 $\mathrm{ml} / \mathrm{dish}$ of complete medium containing $2 \mathrm{ng} / \mathrm{ml}$ GM-CSF. On culture day 3 , another $10 \mathrm{ml}$ of fresh complete medium containing $2 \mathrm{ng} / \mathrm{ml} \mathrm{GM-CSF}$ was added, and on day 6 half of the medium was changed. On day 8 , non-adherent and loosely adherent DCs were harvested by vigorous pipetting and used as immature DCs (iDCs). iDCs recovered from these cultures were generally $>85 \% \mathrm{CD} 11 \mathrm{c}^{+}$and MHC-class II ${ }^{\text {med-high }}$, CD80 ${ }^{\text {med }}$, and CD86 ${ }^{\text {low-med }}$. Phenotypic maturation of DCs was analyzed by flow cytometry. Cell staining was performed using a combination of FITC-conjugated anti-MHC-class II and PE-conjugated CD11C antibody. Cells were analyzed using a FACSCalibur flow cytometer (BD Biosciences, San Jose, CA), and data were analyzed using WinMdi software (Scripps, La Hoya, CA). Forward and side scatter parameters were used to gate live cells.

\section{In vivo toxicity}

Female C57BL/6 mice (6-8 weeks old) were obtained from Korea Research Institute (Chungbuk, Korea). Mice were housed in specific pathogen-free conditions at $21-24^{\circ} \mathrm{C}$ and $40-60 \%$ relative humidity under a $12 \mathrm{~h}$ light/dark cycle. All animals were acclimatized for at least 1 week prior to the experiments. The experimental procedures used in this study were approved by the KRIBB Animal Experimentation Ethics Committee. Mice were administered TPM at doses from 3 to $100 \mathrm{mg} / \mathrm{kg}$ ip once a day for 4 days (Follett et al., 2004; Park et al., 2008). On day 5 , mice were sacrificed and the changes in the immune organs were examined.

\section{Statistics}

Results represent the mean values of more than three samples and five mice. Standard deviations (SD) were compared using the Student's t test and $p$ values were calculated by ANOVA (GraphPad Software, San Diego, CA) (Kim et al., 2008). 


\section{RESULTS}

In the present study, we investigated the effects of TPM on the immune responses of major immune cells, such as $B$ cells, T cells, dendritic cells, and macrophages. We used two different types of macrophages, namely brain-localized microglial cells (BV2) and peripheral tissue-localized macrophages (RAW 264.7 cells).

\section{Effect of TPM on microglial cell function}

To investigate whether TPM affected microglial cell functions, we used the BV2 murine microglial cell line. As shown in Fig. 1A, the basal level of NO production in BV2 cells was quite low and was not changed by TPM treatment. Upon exposure to LPS, BV2 cells produced high levels of NO over basal (Fig. 1B). However, TPM did not change NO production by LPS-activated BV2 cells. These data suggest that TPM does not affect immune functions of BV2 microglial cells, which were brain-lo-

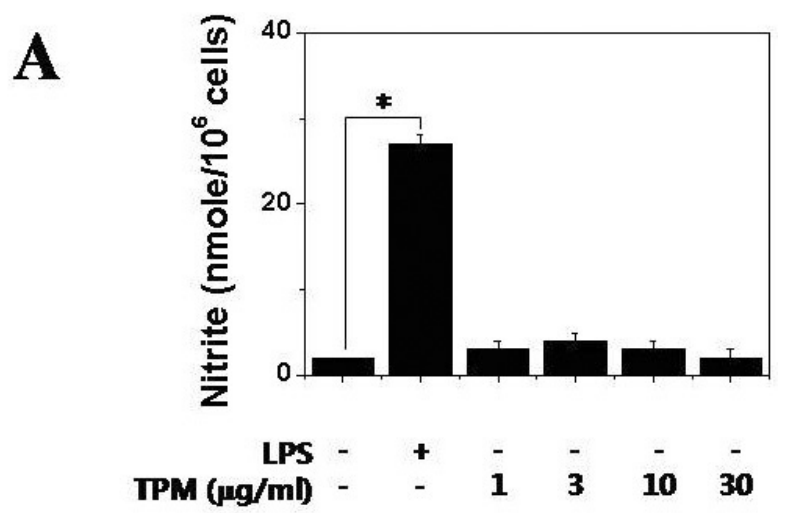

B

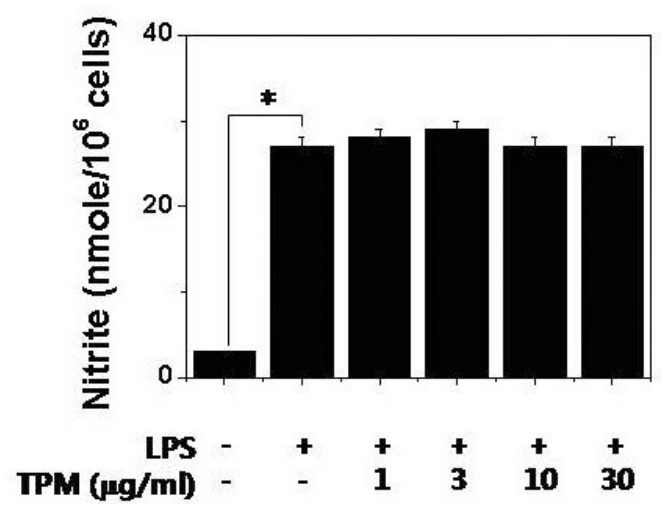

Fig. 1. Effect of topiramate on NO production in BV2 cells. BV2 cells were treated with topiramate (TPM) for $24 \mathrm{hr}$ and the isolated supernatants were mixed with an equal volume of Griess reagent $(A)$. BV2 cells were treated with TPM and LPS (1 $\mu \mathrm{g} / \mathrm{ml})$ as an activator. After $24 \mathrm{hr}$, the isolated supernatants were mixed with an equal volume of Griess reagent (B). Significance was determined by ANOVA $\left({ }^{*} p<0.05\right)$. calized macrophages.

\section{Effect of TPM on macrophage function}

Next, we examine the effect of TPM on peripheral macrophages by using RAW 264.7 cell lines. Un-stimulated RAW 264.7 cells showed only a small amount of NO production, which was not changed by TPM treatment (Fig. 2A). LPS-treated RAW 264.7 cells showed enhanced NO production of $18 \mathrm{nmole} / 10^{6}$ cells $24 \mathrm{hr}$ after treatment. However, TPM did not affect NO production by LPS-treated macrophages. Overall, these data suggest that TPM does not affect the immune functions of RAW 264.7 peripheral macrophages or BV2 brain macrophages.

\section{Effect of TPM on B and T cell proliferation}

We examined the effects of TPM on lymphocytes, such as $B$ cells and $T$ cells. We induced specific $B$ cell proliferation with LPS and specific $\mathrm{T}$ cell proliferation with

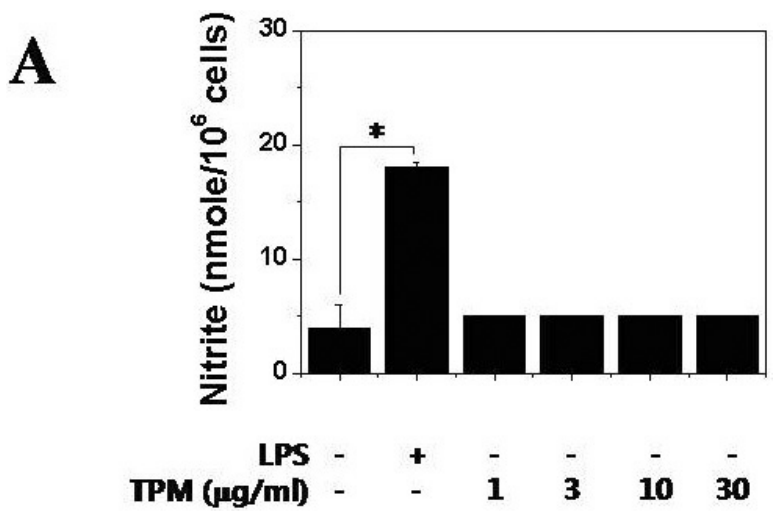

B

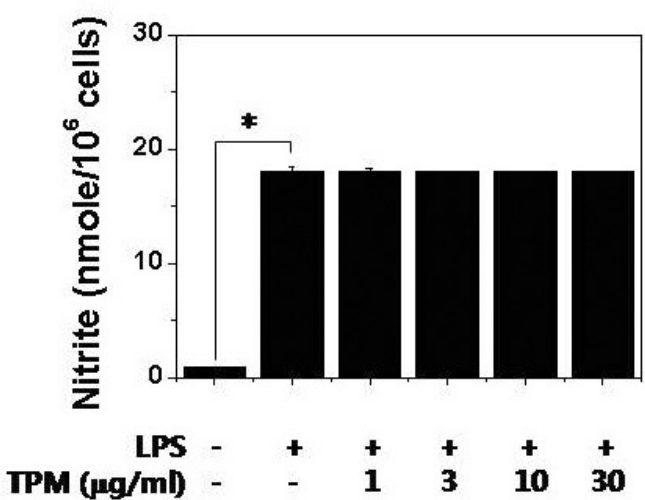

Fig. 2. Effect of topiramate on NO production in RAW 264.7 cells. Cells were treated with topiramate (TPM) for $24 \mathrm{hr}$ and the isolated supernatants were mixed with an equal volume of Griess reagent (A). RAW 264.7 cells were treated with TPM and LPS $(1 \mu \mathrm{g} / \mathrm{ml})$ as an activator. After $24 \mathrm{hr}$, the isolated supernatants were mixed with an equal volume of Griess reagent (B). Significance was determined by ANOVA $\left({ }^{*} p<0.05\right)$. 
$\mathbf{A}$
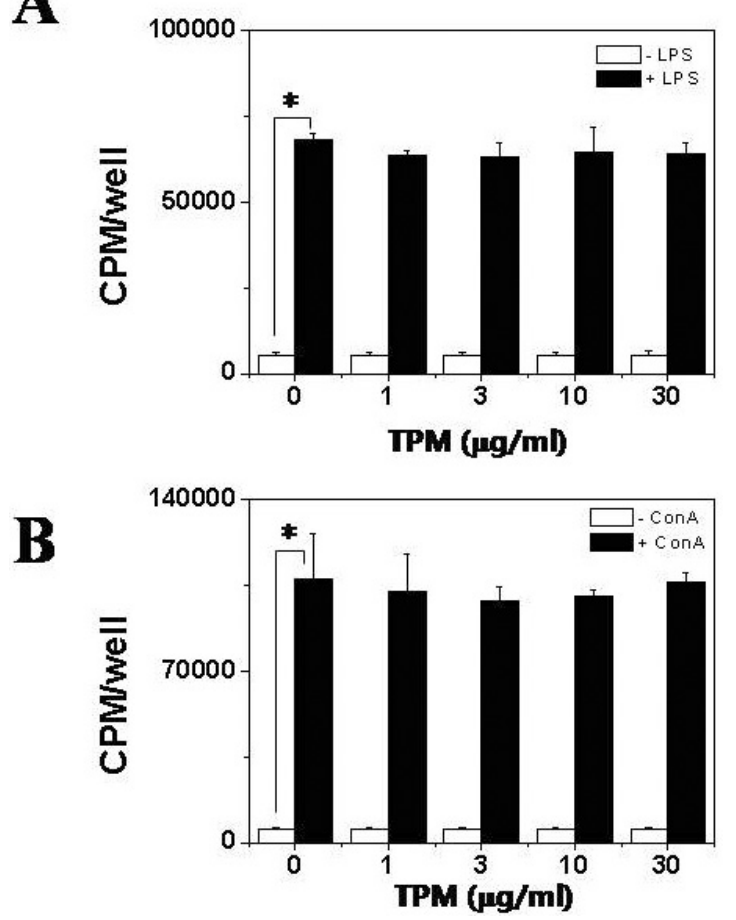

Fig. 3. Effect of topiramate on lympho-proliferation. LPS was used to induce specific B cell proliferation. Spleen cells were incubated with topiramate (TPM) and/or LPS $(1 \mu \mathrm{g} / \mathrm{ml})$ for $72 \mathrm{hr}$ (A). ConA was used to induce specific $T$ cell proliferation. Spleen cells were incubated with topiramate (TPM) and/or ConA ( $1 \mu \mathrm{g} / \mathrm{ml})$ for $72 \mathrm{hr}(\mathrm{B})$. TPM was also treated naive spleen cells in the absence of LPS or ConA. Cells were pulsed with 1 $\mu \mathrm{Ci} /$ well of $\left[{ }^{3} \mathrm{H}\right]$-thymidine $(113 \mathrm{Ci} / \mathrm{nmol})$ for the last $18 \mathrm{hr}$ and harvested with an automated cell harvester. The amount of $\left[{ }^{3} \mathrm{H}\right]$-thymidine incorporated into the cells was measured using a Wallac Microbeta scintillation counter. Significance was determined by ANOVA versus vehicle-treated controls $\left({ }^{*} p<\right.$ $0.05)(A)$. Significance was determined by ANOVA $\left({ }^{*} p<0.05\right)$.

ConA. TPM did not inhibit basal proliferation of splenic B/T cells (Fig. 3). TPM did not affect LPS-induced B cell proliferation (Fig. 3A) and ConA-induced $T$ cell proliferation (Fig. 3B). These data suggest that TPM is a safe drug that does not affect the immune functions of $B$ and $T$ cells.

\section{Effect of TPM on dendritic cell functions}

We investigated the effect of TPM on dendritic cells. Immature DCs were generated from BM precursors by treating with $2 \mathrm{ng} / \mathrm{ml}$ of GM-CSF. On day 8 of culture, non-adherent and loosely adherent cells, i.e., immature DCs, were harvested from cultures. An analysis of cell surface markers showed that more than $85 \%$ of cells were CD11c+, but not CD3+ or B220+ (Kim et al., 2007). Immature DCs were treated with LPS for $24 \mathrm{hr}$ to induce maturation and TPM was added to cultures to investigate whether TPM affected the DC maturation process. The basal level of mean fluorescence intensity (MFI) of MHCclass II expression was low in immature DCs and was not changed by TPM (Fig. 4). Upon exposure to LPS, MHC-II expression was strongly up-regulated, whereas TPM did not change its expression. These data demonstrate that TPM does not affect DC maturation. Overall, the above data suggest that TPM does not affect the immune functions of microglial cells, macrophages, B cells, T cells, and DCs in vitro, and can be considered a safe drug that will not to induce adverse immunological effects.

\section{Effect of TPM on in vivo immune organs}

Finally, we examined the in vivo effect of TPM on immune systems. We administered TPM to C57BL/6 mice for 4 consecutive days and examined the changes in immune organs. As shown in Fig. 5, TPM did not affect the body weight of mice during treatment, suggesting that TPM does not induce severe toxicity. After the TPM treatment, we also examined the weights of immune organs, inguinal and popliteal lymph nodes, spleen, and thymus; TPM did not affect their weights (Table I). When we examined total cell number and cellularity with antibodies against B200, CD3, CD4, and CD8 in inguinal and popliteal lymph nodes and spleen, there were no changes (data not shown). However, TPM at high concentrations $(100 \mathrm{mg} / \mathrm{kg}$ ) slightly reduced the weights of kidney and liver. Overall, TPM appears to be a safe drug that does not induce severe adverse immunological effects.

\section{DISCUSSION}

In this study, we investigated the effect of TPM on the functions of microglial cells and several immune cells. Microglial cells are specialized macrophages capable of inducing inflammation in the brain. Several reports have proposed that inflammation is induced during and after seizure activity (Ben-Menachem, 2003; Haghikia et al., 2008). Indeed, in a previous study, an increase in proinflammatory mediators, particularly IL-1 and nitric oxide, was detected in experimental epilepsy models (De Simoni et al., 2000). In addition, inflammatory mediators were detected in the fluid from epileptic patients (Peltola et al., 2000); however, these were cases of chronic rather than acute seizures. Microglial cells might play a role in cytokine production in the brain (Hanisch, 2002), suggesting that chronic seizure triggered activation of microglial cells. Levetracetam, which has anti-epileptic efficacy, has been shown to inhibit inflammation in patients (Haghikia et al., 2008). Further- 


\section{A $\quad$ TPM $(\mu \mathrm{g} / \mathrm{ml})$}

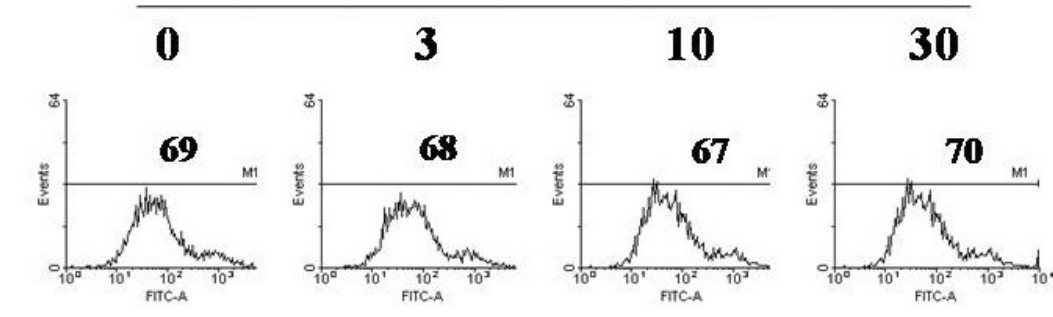

Fig. 4. Effect of topiramate on the maturation of DCs. Immature DCs (iDCs) were generated from mouse bone marrow cells by treating them with 2 $\mathrm{ng} / \mathrm{ml}$ of GM-CSF for 8 days; iDCs were then treated with topiramate (TPM) for $24 \mathrm{hr}(\mathrm{A})$. In another experiment, immature DCs were activated

B LPS + TPM $(\mu \mathrm{g} / \mathrm{ml})$
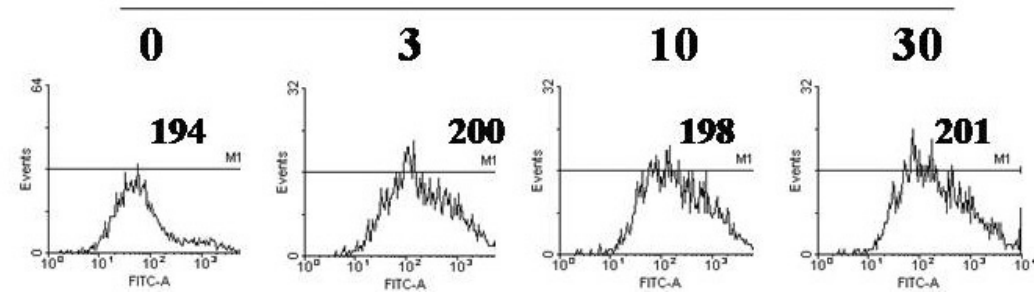
with LPS $(1 \mu \mathrm{g} / \mathrm{ml})$ to induce maturation and with TPM simultaneously for $24 \mathrm{hr}$ (B). Non-adherent and loosely adherent cells were harvested and stained with two Abs, i.e., PE-conjugated CD11c $\mathrm{Ab}$ and FITC- conjugated Abs to MHC-II. CD11C$P E$ was used to gate DCs. Histograms and mean fluorescence intensities (MFI) are shown. Results are representative of more than three separate experiments.

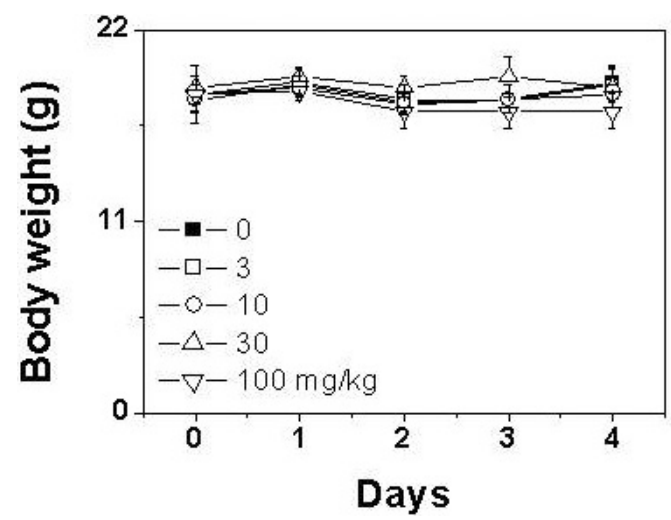

Fig. 5. In vivo effect of topiramate on immune organs. C57BL/6 mice $(n=4)$ were administered topiramate (TPM) at doses from 3 to $100 \mathrm{mg} / \mathrm{kg}$ ip once a day for 4 days. Body weight was measured daily to estimate toxicity of TPM. Control mice were injected with PBS, which was used to dissolve TPM.

more, levetracetam had a preventive effect on impairment of astroglial regulatory properties under inflammatory conditions. However, TPM was likely different from other AEDs in modulation of inflammation. In this study, we showed that TPM was ineffective for inhibiting inflammation. TPM could not directly inhibit LPS-induced activation of microglial cells or other inflammatory immune cells. However, we cannot exclude the possibility that TPM might inhibit chronic inflammation in patients after prolonged treatment. We are currently devising experiments to examine the effect of prolonged TPM on inflammation under seizure conditions, since the anti-inflammatory activity of AEDs is typi- cally shown in chronic cases.

The primary goals of AED treatment are to achieve complete seizure freedom, ideally without adverse events, to reduce morbidity, mortality, and seizure-related accidents, and to improve quality of life. This can be achieved with several widely-used AEDs, such as lamotrigine, levetiracetam, and topiramate, in approximately $75 \%$ of epileptic patients (Bootsma et al., 2008a; Bootsma et al., 2008b). However, new AEDs are still needed for the remaining refractory epileptic patients, and some studies have shown promising results in this refractory population (Callaghan et al., 2007; Luciano and Shorvon, 2007). Due to the diversity of AEDs, both novel and classical, it is often somewhat difficult for clinicians to choose which drug to prescribe for which patient. One method for drug selection is to use information from large multicenter randomized controlled trials, but such trials have been rare for these drugs. Another method is to compare the intrinsic properties of AEDs, such as mode of action, efficacy, safety, and so on. Still another way is to use retention rates; prolonged retention of patients on their AED therapy is now accepted as a clear reflection of therapeutic efficacy (Bootsma et al., 2006; Bootsma et al., 2007). Retention rate also represents a measure of efficacy and safety. Although it is not clear whether efficacy and safety contribute equally to the clinical application of AEDs, one study mentions that safety, rather than efficacy, might be related to retention rate (Chung et al., 2007). Also, according to this study, a drug that was only modestly efficacious but had a favorable safety profile might seem better than a drug that was more 
Table I. Changes in the immune organ weights with TPM treatment

\begin{tabular}{lccccc}
\hline \multirow{2}{*}{ Organs $(\mathrm{mg})$} & \multicolumn{5}{c}{ Topiramate $(\mathrm{mg} / \mathrm{kg})$} \\
\cline { 2 - 6 } & 0 & 3 & 10 & 30 & 100 \\
\hline Popliteal lymph node & $0.7 \pm 0.2$ & $0.8 \pm 0.1$ & $0.7 \pm 0.4$ & $0.8 \pm 0.3$ & $0.7 \pm 0.3$ \\
Inguinal lymph node & $3.2 \pm 0.2$ & $2.8 \pm 0.4$ & $2.9 \pm 0.6$ & $2.8 \pm 0.5$ & $3.0 \pm 0.5$ \\
Spleen & $81 \pm 5$ & $82 \pm 4$ & $75 \pm 6$ & $79 \pm 10$ & $77 \pm 8$ \\
Thymus & $74 \pm 5$ & $81 \pm 9$ & $115 \pm 4$ & $73 \pm 7$ & $80 \pm 5$ \\
Kidney & $118 \pm 6$ & $120 \pm 6$ & $1,009 \pm 51$ & $1,027 \pm 108$ & $110 \pm 5^{\star}$ \\
Liver & $1,003 \pm 86$ & $1,126 \pm 58$ &
\end{tabular}

Significance was determined by ANOVA versus vehicle-treated controls $\left({ }^{*} p<0.05\right)$.

efficacious but produced adverse effects. Therefore, side effect profiles might be the determining factor for retention rate. Here, we examined the safety of TPM, especially from the immunological aspect. TPM did not affect the immune functions of B cells, T cells, dendritic cells, peripheral macrophages, or brain macrophages. Together with the proven therapeutic efficacy of TPM, our data suggested that TPM is a valuable option for the treatment of patients with epilepsy.

In conclusion, the results of our study showed that TPM did not affect the functions of immune cells, such as microglial cells, macrophages, B cells, T cells, and dendritic cells. We conclude that TPM is an immunologically safe drug without severe adverse effects.

\section{ACKNOWLEDGMENTS}

This work was supported by the Research Grant funded by Janssen Korea Ltd. and by the grant of the Korean Ministry of Education, Science and Technology (The Regional Core Research Program/Chungbuk BIT ResearchOriented University Consortium).

\section{REFERENCES}

Ben-Menachem, E. (1996). Expanding antiepileptic drug options: clinical efficacy of new therapeutic agents. Epilepsia 37 (Suppl 2), S4-S7.

Ben-Menachem, E. (2003). Levetiracetam: treatment in epilepsy. Expert Opin. Pharmacother. 4, 2079-2088.

Ben-Menachem, E., Henriksen, O., Dam, M., Mikkelsen, M., Schmidt, D., Reid, S., Reife, R., Kramer, L., Pledger, G. and Karim, R. (1996). Double-blind, placebo-controlled trial of topiramate as add-on therapy in patients with refractory partial seizures. Epilepsia 37, 539-543.

Bootsma, H. P., Aldenkamp, A. P., Diepman, L., Hulsman, J., Lambrechts, D., Leenen, L., Majoie, M., Schellekens, A. and de Krom, M. (2006). The effect of antiepileptic drugs on cognition: patient perceived cognitive problems of topiramate versus levetiracetam in clinical practice. Epilepsia $\mathbf{4 7}$
(Suppl 2), 24-27.

Bootsma, H. P., Ricker, L., Diepman, L., Gehring, J., Hulsman, J., Lambrechts, D., Leenen, L., Majoie, M., Schellekens, A., de Krom, M. and Aldenkamp, A. P. (2007). Levetiracetam in clinical practice: long-term experience in patients with refractory epilepsy referred to a tertiary epilepsy center. Epilepsy Behav. 10, 296-303.

Bootsma, H. P., Ricker, L., Diepman, L., Gehring, J., Hulsman, J., Lambrechts, D., Leenen, L., Majoie, M., Schellekens, A., de Krom, M. and Aldenkamp, A. P. (2008a). Long-term effects of levetiracetam and topiramate in clinical practice: $A$ head-to-head comparison. Seizure 17, 19-26.

Bootsma, H. P., Vos, A. M., Hulsman, J., Lambrechts, D., Leenen, L., Majoie, M., Savelkoul, M., Schellekens, A. and Aldenkamp, A. P. (2008b). Lamotrigine in clinical practice: long-term experience in patients with refractory epilepsy referred to a tertiary epilepsy center. Epilepsy Behav. 12, 262-268.

Callaghan, B. C., Anand, K., Hesdorffer, D., Hauser, W. A. and French, J. A. (2007). Likelihood of seizure remission in an adult population with refractory epilepsy. Ann. Neurol. 62, 382-389.

Chung, S., Wang, N. and Hank, N. (2007). Comparative retention rates and long-term tolerability of new antiepileptic drugs. Seizure 16, 296-304.

De Simoni, M. G., Perego, C., Ravizza, T., Moneta, D., Conti, M., Marchesi, F., De Luigi, A., Garattini, S. and Vezzani, A. (2000). Inflammatory cytokines and related genes are induced in the rat hippocampus by limbic status epilepticus. Eur. J. Neurosci. 12, 2623-2633.

DeLorenzo, R. J., Sombati, S. and Coulter, D. A. (2000). Effects of topiramate on sustained repetitive firing and spontaneous recurrent seizure discharges in cultured hippocampal neurons. Epilepsia 41(Suppl 1), S40-44.

Faught, E., Wilder, B. J., Ramsay, R. E., Reife, R. A., Kramer, L. D., Pledger, G. W. and Karim, R. M. (1996). Topiramate placebo-controlled dose-ranging trial in refractory partial epilepsy using 200-, 400-, and 600-mg daily dosages. Topiramate YD Study Group. Neurology 46, 1684-1690.

Follett, P. L., Deng, W., Dai, W., Talos, D. M., Massillon, L. J., Rosenberg, P. A., Volpe, J. J. and Jensen, F. E. (2004). Glutamate receptor-mediated oligodendrocyte toxicity in periventricular leukomalacia: a protective role for topiramate. J. Neurosci. 24, 4412-4420.

French, J. A., Kanner, A. M., Bautista, J., Abou-Khalil, B., Browne, T., Harden, C. L., Theodore, W. H., Bazil, C., Stern, 
J., Schachter, S. C., Bergen, D., Hirtz, D., Montouris, G. D., Nespeca, M., Gidal, B., Marks, W. J. Jr., Turk, W. R., Fischer, J. H., Bourgeois, B., Wilner, A., Faught, R. E. Jr., Sachdeo, R. C., Beydoun, A. and Glauser, T. A. (2004a). Efficacy and tolerability of the new antiepileptic drugs I: treatment of new onset epilepsy: report of the therapeutics and technology assessment subcommittee and quality standards subcommittee of the american academy of neurology and the american epilepsy society. Neurology 62, 12521260.

French, J. A., Kanner, A. M., Bautista, J., Abou-Khalil, B., Browne, T., Harden, C. L., Theodore, W. H., Bazil, C., Stern, J., Schachter, S. C., Bergen, D., Hirtz, D., Montouris, G. D., Nespeca, M., Gidal, B., Marks, W. J. Jr., Turk, W. R., Fischer, J. H., Bourgeois, B., Wilner, A., Faught, R. E. Jr., Sachdeo, R. C., Beydoun, A. and Glauser, T. A. (2004b). Efficacy and tolerability of the new antiepileptic drugs, I: Treatment of new-onset epilepsy: report of the TTA and QSS Subcommittees of the American Academy of Neurology and the American Epilepsy Society. Epilepsia 45, 401-409.

Gibbs, J. W. 3rd, Sombati, S., DeLorenzo, R. J. and Coulter, D. A. (2000). Cellular actions of topiramate: blockade of kainate-evoked inward currents in cultured hippocampal neurons. Epilepsia 41(Suppl 1), S10-16.

Haghikia, A., Ladage, K., Hinkerohe, D., Vollmar, P., Heupel, K., Dermietzel, R. and Faustmann, P. M. (2008). Implications of antiinflammatory properties of the anticonvulsant drug levetiracetam in astrocytes. J. Neurosci. Res. 86, 1781-1788.

Han, S. B., Kim, Y. H., Lee, C. W., Park, S. M., Lee, H. Y., Ahn, K. S., Kim, I. H. and Kim, H. M. (1998). Characteristic immunostimulation by angelan isolated from Angelica gigas Nakai. Immunopharmacology 40, 39-48.

Hanisch, U. K. (2002). Microglia as a source and target of cytokines. Glia 40, 140-155.

Jeon, Y. J., Han, S. B., Ahn, K. S. and Kim, H. M. (2000). Differential activation of murine macrophages by angelan and LPS. Immunopharmacology 49, 275-284.

Kim, H. M., Kang, J. S., Park, S. K., Lee, K., Kim, J. Y., Kim, Y. J., Hong, J. T., Kim, Y. and Han, S. B. (2008). Antidiabetic activity of angelan isolated from Angelica gigas Nakai. Arch. Pharm. Res. 31, 1489-1496.

Kim, J. Y., Yoon, Y. D., Ahn, J. M., Kang, J. S., Park, S. K., Lee, K., Song, K. B., Kim, H. M. and Han, S. B. (2007). Angelan isolated from Angelica gigas Nakai induces dendritic cell maturation through toll-like receptor 4. Int. Immunopharmacol. 7, 78-87.

Latini, G., Verrotti, A., Manco, R., Scardapane, A., Del Vecchio, A. and Chiarelli, F. (2008). Topiramate: its pharmacological properties and therapeutic efficacy in epilepsy. Mini. Rev. Med. Chem. 8, 10-23.

Luciano, A. L. and Shorvon, S. D. (2007). Results of treatment changes in patients with apparently drug-resistant chronic epilepsy. Ann. Neurol. 62, 375-381.

Lyseng-Williamson, K. A. and Yang, L. P. (2007). Topiramate: a review of its use in the treatment of epilepsy. Drugs 67, 2231-2256.

Lyseng-Williamson, K. A. and Yang, L. P. (2008). Spotlight on topiramate in epilepsy. CNS Drugs 22, 171-174.

Maryanoff, B. E., Nortey, S. O., Gardocki, J. F., Shank, R. P. and Dodgson, S. P. (1987). Anticonvulsant O-alkyl sulfamates. 2,3:4,5-Bis-O-(1-methylethylidene)-beta-D-fructopyranose sulfamate and related compounds. J. Med. Chem. 30, 880887.

Moon, E. Y., Oh, S. Y., Han, G. H., Lee, C. S. and Park, S. K. (2005). Epac1-mediated Rap1 activation is not required for the production of nitric oxide in BV2, murine microglial cells. J. Neurosci. Res. 81, 38-44

Park, H. J., Kim, H. J., Park, H. J., Ra, J., Zheng, L. T., Yim, S V. and Chung, J. H. (2008). Protective effect of topiramate on kainic acid-induced cell death in mice hippocampus. Epilepsia 49, 163-167.

Peltola, J., Palmio, J., Korhonen, L., Suhonen, J., Miettinen, A., Hurme, M., Lindholm, D. and Keranen, T. (2000). Interleukin-6 and interleukin-1 receptor antagonist in cerebrospinal fluid from patients with recent tonic-clonic seizures. Epilepsy Res. 41, 205-211.

Privitera, M., Fincham, R., Penry, J., Reife, R., Kramer, L., Pledger, G. and Karim, R. (1996). Topiramate placebocontrolled dose-ranging trial in refractory partial epilepsy using 600-, 800-, and 1,000-mg daily dosages. Topiramate YE Study Group. Neurology 46, 1678-1683.

Rosenfeld, W. E. (1997). Topiramate: a review of preclinical, pharmacokinetic, and clinical data. Clin. Ther. 19, 1294 1308.

Rosenfeld, W. E., Doose, D. R., Walker, S. A. and Nayak, R. K (1997). Effect of topiramate on the pharmacokinetics of an oral contraceptive containing norethindrone and ethinyl estradiol in patients with epilepsy. Epilepsia 38, 317-323.

Sachdeo, R. C., Sachdeo, S. K., Levy, R. H., Streeter, A. J., Bishop, F. E., Kunze, K. L., Mather, G. G., Roskos, L. K., Shen, D. D., Thummel, K. E., Trager, W. F., Curtin, C. R., Doose, D. R., Gisclon, L. G. and Bialer, M. (2002). Topiramate and phenytoin pharmacokinetics during repetitive monotherapy and combination therapy to epileptic patients. Epilepsia 43, 691-696.

Sharief, M., Viteri, C., Ben-Menachem, E., Weber, M., Reife, R. Pledger, G. and Karim, R. (1996). Double-blind, placebocontrolled study of topiramate in patients with refractory partial epilepsy. Epilepsy Res. 25, 217-224.

Shorvon, S. D. (1996). Safety of topiramate: adverse events and relationships to dosing. Epilepsia 37(Suppl 2), S18-S22.

Tassinari, C. A., Michelucci, R., Chauvel, P., Chodkiewicz, J., Shorvon, S., Henriksen, O., Dam, M., Reife, R., Pledger, G. and Karim, R. (1996). Double-blind, placebo-controlled trial of topiramate (600 mg daily) for the treatment of refractory partial epilepsy. Epilepsia 37, 763-768.

Wasserstein, M. L. and Hedges, D. W. (1995). Nephrolithiasis during treatment with topiramate. Epilepsia 36, 153.

White, H. S. (1997). Clinical significance of animal seizure models and mechanism of action studies of potential antiepileptic drugs. Epilepsia 38(Suppl 1), S9-17.

White, H. S., Brown, S. D., Woodhead, J. H., Skeen, G. A. and Wolf, H. H. (1997). Topiramate enhances GABA-mediated chloride flux and GABA-evoked chloride currents in murine brain neurons and increases seizure threshold. Epilepsy Res. 28, 167-179.

Yen, D. J., Yu, H. Y., Guo, Y. C., Chen, C., Yiu, C. H. and Su, M. S. (2000). A double-blind, placebo-controlled study of topiramate in adult patients with refractory partial epilepsy. Epilepsia 41, 1162-1166. 